\title{
The Love of Money, Pressure to Perform and Unethical Marketing Behavior in the Cosmetic Industry in Uganda
}

\author{
Stephen Korutaro Nkundabanyanga (Corresponding author) \\ Makerere University Business School \\ Plot M118, Portbell Road, PO box 28423, Kampala, Uganda \\ E-mail: hodaccounting@mubs.ac.ug
}

Bruce Mpamizo

Movit Products Ltd

Zana-Bunamwaya, Entebbe Road, PO box 27109, Kampala, Uganda

E-mail: bruce_mpamizo@yahoo.com

Charles Omagor

Makerere University Business School

Plot M118, Portbell Road, PO box 1337, Kampala, Uganda

E-mail: comagor@mubs.ac.ug

Joseph Mpeera Ntayi

Plot M118, Portbell Road, PO box 1337, Kampala, Uganda

E-mail: jntayi@mubs.ac.ug

Received: June 22, $2011 \quad$ Accepted: August 31, $2011 \quad$ Published: November 1, 2011

doi:10.5539/ijms.v3n4p40 URL: http://dx.doi.org/10.5539/ijms.v3n4p40

\begin{abstract}
The purpose of the study was to examine the relationship between love of money, pressure to perform and unethical marketing behavior in the cosmetic industry in Uganda. The methodology was cross-sectional and correlational. A questionnaire was administered to collect data on a sample of 169 marketers selected randomly from five cosmetic companies in Uganda. Results indicate that if the salespersons are willing to perform unprofessional assignments for monetary gain or if they have a burning desire for success regardless of how they should succeed, this is bound to result into unethical marketing behavior. Furthermore, the present study reveals that as pressure to perform increases through the achievement of targets and deadlines, unethical behavior increases and moves in the same direction as a result of the effect. Unrealistic targets combined with fixed deadlines promote and strengthen unethical marketing behavior. Thus love of money through its components, Success, Motivator, Evil, Budget and Equity can be moderated by management control - as management control improves, unethical marketing behavior is minimized. Even if the cosmetics industry in Uganda is very much in its infancy with only five manufacturers and this may limit generalizability, this study argues that companies should employ staff with good working experience in the marketing profession and there should be continuous staff screening of their behaviors over the years. Company image should be a top priority and management should design targets that are realistic to avoid continuous reported unethical behaviors among their staff.
\end{abstract}

Keywords: Money, Pressure to perform, Ethics, Cosmetics, Uganda

\section{Introduction}

Financial scandals and corruption in both private and public organizations have increasingly raised serious concerns among the public (Tang, Chen and Sutarso, 2008) especially in this era of the global financial crisis. 
Corruption cases in Uganda's press are a daily phenomenon and it is so common that some people believe it to be part of 'the national culture' (Royal Netherlands Embassy, 2003). It is important for companies to observe that ethical behaviors of sales people are of central importance in creating and sustaining customers (Gundlach \& Murphy, 1993). Thus, unethical salespersons' behavior can lead to devastating marketing consequences (Boedecker, et al, 1991). Sales professionals meet greater ethical pressure as compared to employees in other jobs (Roman and Munuera, 2005). These sales professionals execute their duties more independently and are in charge of the organization's most valuable section of revenue generation. This puts them under pressure as they are usually appraised basing on short-term/operational targets (Wotruba, (1990) in Roman and Munuera, 2005). It is therefore possible that pressure to perform can lead to unethical marketing behaviors. The love of money measured by Money Ethic Scale (MES) or Love of Money Scale (LOMS) is the major factor considered to lead to unethical behaviors (Tang and Chiu, 2003). However, there is limited research about the relationship between money attitudes and work related attitudes (Li-Ping Tang, Shin-Hsiung Tang and Luna-Arocas, 2005) among which are the marketing unethical behaviors.

Management is challenged to support and model ethical behavior. According to the president and CEO of American Management Association; Edward T. Reilly, (2009) "Corporate leaders need to communicate ethical values throughout the organization, but they must do more than talk the talk in order to establish and sustain an ethical culture" (HR.BLR.com, 2009). It can therefore be argued that management control could facilitate positively or negatively the marketing ethical behaviors in an organization.

The cosmetics industry in Uganda, which is the main focus of the study, has caught up with the world's cosmetic industry trend; growing at an annual rate of 7\% (Yu and Dean 2001). These authors however further observed that a significant number of sales persons entering the industry end up quitting the market in less than two years contrary to what used to happen and that neglecting ethical components of the industry may be the root cause. The players in Uganda's cosmetic industry are Movit, Samona, Neem, AVIS, Skin doctor, NeviA, Desire and Sleeping baby. However, according to their Human Resource Management reports from 2004 to 2009, there is an increasing labour turnover in form of summary dismissals; for instance such unethical cases which resulted in dismissals have increased from $50 \%$ to $72 \%$, on average. Such unethical marketing behaviours include misusing Company assets such as airtime, conducting personal business, falsifying field records, providing basic information to competitors, overcharging customers, stealing samples, disappearing with company money, destroying competitors' displays, telling lies, concealment and revealing confidential information in order to gain favour from customers (Marketing Manager's End of year report, Dec 2009). This situation features as an annual event at Board meetings. It is might be factors within management or the market that tend to cause the situation. Those in the market might be related to competition from other proprietors, relationships with suppliers, and above all, love of money and pressure to perform on the cosmetic usage. Moreover, understanding what underlies salesperson's behavior is a pre-requite to successful marketing. Thus, when more and more marketers engage in unethical behaviors, it is not far-fetched to question whether love for money, pressure to perform and management control play a role in the whole scenario. Therefore, the purpose of the study was to examine the relationship between love of money, pressure to perform and unethical behaviors in the cosmetic industry as a reference case. It is significant for management to consider such relationships more seriously when dealing with marketing practice in general and cosmetic industry in particular. The rest of the paper is organized as follows.

\section{Informing literature and hypotheses development}

\subsection{Love of money}

According to Tang and Chiu (2003) the love of money other than money per-se is the cause of unethical behaviors. 'Love of money' is subject to multiple meanings. Tang et al (2005) refers to love of money as an individual's personalized attitude towards money. On the other hand, Sloan (2002) looked at love of money as the desire of money or greed as distinguished from an individual's needs. Love of money can be analyzed by looking at money profiles and measured using Money Ethic Scale (MES) or Love of Money Scale (LOM) since these money profiles have a direct impact on work-related attitudes (Li-Ping Tang, Shin-Hsiung Tang and Luna-Arocas, 2005). Money attitude components include; Success, Motivator, Evil, Budget and Equity.

The factor evil is the affective component of the money attitude and according to this factor; people believe that the love of money is the cause of all undesirable behaviors (Tang, et al, 2002 in Tang, et al, 2003). This leads to the perception that money is dirty and hence individuals with such belief have developed hatred for it. Budget is the behavioral component of the money attitude and refers to control and proper management of money (Tang et al, 2003). Equity is related to pay fairness comprising of 'individual equity' and 'internal equity'. The argument for 'individual equity' is that individuals who achieve higher quality and quantity of performance have to be 
rewarded better than their counterparts with same job, duties and responsibilities but with a less performance (Gabris \& Mitchell, 1988 quoted Matthew 13:12 in Tang, et al, 2003). For 'internal equity' the argument is that individuals in charge of higher order duties and responsibilities have to be paid more money than those at lower levels in the organizational hierarchy.

The factor success emphasizes money as an indicator of status in society leading to some people being obsessed with money to prove their success (Furnham \& Argyle, 1998). The factor motivator shows that money drives the achievement of goals (Lawler, 1978 in Tang, et al 2003). This implies that people are compelled to work in order to earn money and the more money that is given, the more they can work or where they are paid on commission basis, they will work harder to earn more money. According to Omagor, Mubiru and Nkuutu (2009), basing on press reports and court corruption cases, love of money is very high in Uganda. The authors further assert that, this love of money is mainly associated with need for survival and success other than the evil perspective. These unethical practices are still daily phenomena in press reports, parliamentary debates and court cases in Uganda especially in relation to Global Fund and CHOGM Fund embezzlement. In the business sector, Barigaba (2009) reported a case of a general manager of a large utility company as being involved in cheating customers to generate high profits for his company. The need to investigate whether love of money influences unethical behaviors is therefore valid and timely. This leads to our first hypothesis:

\section{H1: The love of money is positively correlated to unethical behaviors of sales personnel.}

\subsection{Pressure to perform}

The success of any organization depends on the ability to identify, implement, monitor and evaluate 'SMART' objectives. SMART objectives are known to be Specific, Measurable, Attainable, Realistic and Time bound. Objectives that are not attainable and unrealistic will therefore put the implementers under pressure to perform and may lead to unethical behavior. In marketing, pressure to perform can be measured by looking at the level and attainability of salespersons' targets and deadlines because putting sales people under pressure is mostly likely to lead to unethical marketing behaviors. The degree of fear and pressure associated with meeting numerical goals and targets also play a major role in fraud availability.

Several researchers have generally pointed out that the real root causes of corporate scandals is over-emphasizing shareholder value maximization with less consideration of other stakeholders (Kochan, 2002, in Tang, et al, 2008). They further argue that many corporations design compensation and profit-sharing programs to align management interests with the shareholder maximization objective. These compensation schemes lead to a huge amount of pressure and opportunities for individual managers and are associated with serious ethical deviations as was the case in the Enron scandal. This is further supported by Ross and Robertson (2003) who noted that performance pressure is a factor which has been shown to affect ethical behavior.

Usually, it is believed that compensation methods relying on commission, quotas and bonuses are likely to exacerbate ethical problems in sales teams, since these kinds of remuneration systems transfer risk to salespeople, and put financial pressure on them to get sales results (Roman \& Munuera, 2005; Tang, et al, 2008). Robertson and Anderson (1993) argue that as salespeople become more established financially and professionally, they experience some alleviation of the pressure to take shortcuts. Consequently, they argue, salespeople who have achieved this standing have the knowledge and skills at hand to be able to resolve ethical dilemmas without the need to violate ethical norms. The same logic can be applied to sales teams in which salespeople have high levels of tactical selling competence. Individuals in these teams can, if they so choose, use the skills they have developed to resolve the ethically-questionable choices they will face without the need to cut corners or break societal norms. Furthermore, in teams where tactical selling performance is relatively high, the team's corresponding superior sales performance will place team members in situations where there is less need for them to adopt unethical action in the first place, since financial and other performance pressures are likely to be reduced, compared to those teams whose tactical capabilities are not as high. As a result, teams with advanced tactical skills will experience less pressure to break ethical norms, whereas the less tactical sales teams will feel forced to use whatever means are at their disposal to achieve their specified goals. It follows therefore that the greater the extent to which sales teams display tactical selling performance, the greater their ethical standards. However, this was refuted, since the extent to which sales teams display high levels of tactical performance is not positively related to higher ethical standards (Cadogan, et al, 2009).

Most sales personnel's are motivated to pursue the profession of marketing because of its uniqueness and perpetual challenge. They are excited by the competition the market provides and by the exhilaration that comes from selling especially under the pressure of competition (Nicklaus and King, 2009). However, sales personnel somewhere along the way; the love of the action in the market might give way to the pressure to perform, 
expectations, desires, frustrations, fear of failure, impatience and anxiety related to the very challenge they loved.

Power issues aside, a possible explanation for this finding is that competitive issues may moderate the positive relationship between tactical performance and ethical standards. Specifically, highly skilled sales teams may perceive less of a need to adopt unethical practices when competitors are not particularly effective: in line with the above argument, the more skilled the team, the less the need for unethical behavior, and the greater the likelihood that ethical standards will be high. However, when competition is fierce, and competitors adopt unethical influence and sales tactics, even highly skilled sales teams may feel a need to rely on more than just their tactical capabilities to achieve success. In this situation, such sales teams may experience competitive pressure to resort to morally questionable activity to generate sales. Clearly, additional research is needed to clarify this issue. We therefore hypothesize that:

\section{H2: Pressure to perform is positively correlated to unethical behaviors of sales personnel.}

\subsection{Management control}

Management controls are comprised of policies, procedures, and systems relating to the reliability of financial reporting. They include approvals, authorisation, verifications, reconciliations, reviews of performance, segregation of duties, and controls over information systems and code of conduct to guide employee behaviour. According to the Sarbanes-Oxley Act of 2002, management controls can be preventive, detective, directive and mitigating. Corrective actions are a necessary complement to ethical behaviour in order to achieve the organisational objectives. Exemplary ethical conduct on the part of management and enforcement of ethical standards and regulations should be central to the overall ethical environment of their firms. In the event managers uphold ethics and integrity, employees will be more inclined to uphold those same values. Six universal ethical values can be identified to include; honesty, integrity, loyalty, responsibility, fairness and citizenship. By acting in good faith (honesty) directors and management might ensure proper corporate governance and shareholder wealth maximisation. Integrity is upholding corporate principles and values should begin from the top. This requires the management to conduct themselves with honour and self respect.

A number of studies have linked unethical behaviour to lack of moral leadership. A case in point being WorldCom's CEO, Bernie Ebbers, whose managerial skills led to fast growth of the company only to be let down by his lack of moral direction (Applebaum, Iaconi \& Matousek, 2007). Management controls and ethical standards may therefore influence ethical marketing behaviors as measured by looking at the availability and strength of ethical standards as well as management commitment to ethical values. This was emphasized by Cadogan, et al (2009) who asserted that in the event of unethical dilemmas, sales people will most likely engage in unethical marketing behaviors when the ethical standards and controls are not properly managed.

It is a sad truth that the employees of just about every business, in every business, will occasionally encounter team members who are taking part in unethical behaviors. Such unethical behaviors include a wide variety of different activities. Among the most common unethical business behaviors of employees are making long-distance calls on business lines, duplicating software for use at home, falsifying the number of hours worked, or much more serious and illegal practices, such as embezzling money from the business, or falsifying business records. Though there is sometimes a difference between behaviors that are unethical and activities that are actually illegal, it is up to the business itself to decide how it deals with unethical behavior - legal or not (Mohamed, 2007). This argument is in line with Ernst and Young Fraud investigation report (2008), which stressed that unethical behavior in all its form, including fraud, is perpetrated by people, and by all employeesnot only by management. However the research further indicated that employees perceive that unethical behavior is not a topic that is considered important by their employers; profit, growth and image are the focus points. When assessing the risk of wrongdoing in and against a company, too much emphasis on profit, growth and image are known to be elements that can increase that risk. Cases like Enron or Ahold are typical examples. It is therefore important to analyze the role of management control in influencing love of money, pressure to perform and unethical marketing behaviors hence the hypothesis:

H3: Management control moderates between love of money, pressure to perform, and unethical marketing behaviors of sales personnel.

\subsection{Demographic factors}

The available literature is not clear about the relationship between demographic factors and unethical behaviours. For instance in one research, it was recommended that professors and researchers should emphasize training especially male students in business ethics (Tang, Chen, Sutarso, 2008). This implied that male students are 
more likely to participate in unethical behaviours also emphasized by Singhapakdi, et al (1999) that women have more ethical intentions than men are. However, there are conflicting views: Rayburn \& Rayburn (1996) argues sex is not a good predictor for unethical behaviour yet, anecdotal evidence in Uganda presents a mixed picture though in most scenarios females are believed to be less likely to engage in unethical behaviour than their male counterparts (UBOS, 2008).

Omagor et al (2009) suggested that the area of residence might predict the tendency to engage in unethical behaviour. But, people's propensity to engage in unethical behaviour might not be dependent on residence but merely on greed and responsibility (family and or office). Omagor, et al (2009) in a study involving university students in Uganda found out that marital status has a moderating effect on the propensity to engage in unethical behaviour. Roman and Munuera (2005) concluded that age is a significant antecedent of ethical behaviour in that older sales people were found to be more ethical than their younger counterparts were.

\section{Methodology}

The study used a cross sectional design and a descriptive approach to ascertain the relationship between love of money, pressure to perform, management control and the propensity of sales representatives to engage in unethical marketing behavior. The population comprised of sales representatives in the marketing department, sales managers and regional managers plus supervisors in the cosmetic industry in Uganda. The population size for consideration in the study was 300 drawn from 5 cosmetic leading manufacturers. This excluded the newly licensed manufacturers because they had not yet established their market shares in the Ugandan market. A total of 300, disaggregated into 230 sales representatives, 20 sales managers, 30 regional managers, and 20 supervisors constituted the total population from the cosmetic manufacturers for the purpose of the study. From a total population of 300, using Krejcie and Morgan (1970), we estimated the ideal sample size to be 169 as per strata. A summary of this is shown in the table 1 below:

\section{Insert Table 1}

The choice of 169 respondents out of 300 was drawn through simple random sampling to give a representative view of love of money, pressure to perform, management control and the propensity to engage in unethical marketing behavior. The researchers picked randomly; 44 sales representatives, 3 sales managers, 6 sales supervisors and 3 regional managers in MOVIT, in samona; 28 sales representatives, 2 sales manager, 6 sales supervisors and 3 regional managers respectively etc. The data used in the research was unavailable in an assembled and condensed form from secondary sources and so the researcher used data based on reports of HR, and Journals. The self-administered questionnaire was designed according to objectives of the study with closeended questions and a few open-ended questions to ensure clarity of response on the themes of the study. Love of money was measured using Success, Motivator, Evil, Budget and Equity using previous studies (Tang \& Chiu, 2003; and Omagor, 2009). This information was obtained from the respondents. Pressure to perform was measured by targets and deadlines. Management control was measured using preventive, detective, directive and mitigating as by institute of internal auditors (COSO, 2009) model. There were certain demographic factors that were necessary to be controlled for, because the previous studies have shown that there is a positive relationship between them and unethical marketing behavior. These included gender, age, marital status, level of education and area of residence (Omagor et al, 2009). To ensure validity and reliability of the instrument the following was followed; Content validity was used, the instruments were given to experts on the topic to agree whether the statements do relate to what they are supposed to measure as it was used from previous studies (Tand \& Chiu, 2003; and Kline,2005) to avoid being vague and ambiguous. For reliability of the instrument the study used Kappa coefficient using on a two-point scale yes, or No. A scientific test was carried out to determine the reliability of the instrument using Chronbach's Alpha, bearing in mind that different researchers have recommended different lower limits, with Sabit (2002), Hair et al (1998) and Straub (1989) recommending 0.5, 0.7 and 0.8 respectively.

\section{Insesrt Table 2}

Data collected from the primary survey was compiled, sorted, edited, classified, coded into a coding sheet and analyzed using Statistical package for social scientist (SPSS) Version 11. Both descriptive statistics (demographic characteristics) and inferential statistics (correlation and regression) were used to determine the degree and relationships between love of money, pressure to perform, management control and unethical behavior. 


\section{Results}

The majority of the respondents $(92 \%)$ were male and this showed male dominance in the industry. The women constituted only $(8 \%)$ of the respondents. This is because the nature of the job of marketing cosmetics required traveling long distances and often offloading the product packages in to retail stores, supermarkets etc which many females find difficult. According to the findings, the majority of the respondents $(62 \%)$ were in the age bracket of $30-39$ years. This could imply that this is the most active and mobile age group which the industry can use in its marketing and other departments. Those in the age bracket of $20-29$ years comprised (35\%). Furthermore, those between $40-49$ years and 50 years and above comprised only (4\%) and (1\%) respectively, implying that those in the above age groups were fewer. $50 \%$ of the respondents were Diploma holders, $28 \%$ were degree holders while $5 \%$ of the staff had attained postgraduate degrees and $14 \%$ were certificate holders. This indicates that majority of marketer staff were diploma holders. However, there was only $3 \%$ respondent in the other category such as Chartered Institute of Marketing. The findings further indicate that of the staff that holds diplomas, $80 \%$ are married. The $85 \%$ of the respondents reside in urban areas and $15 \%$ stay in rural areas. This indicates that majority of marketer staff are urban based.

The results in the table below illustrate the nature of the relationships between the study variables and this was done using the Pearson (r) correlation coefficient. The results in the table 3 indicated that there is a significant positive relationship between the love of money and unethical marketing behavior as shown by the spearman correlation $\left(\mathrm{r}=.675^{* *}, \mathrm{p}<.01\right)$. In addition, it was noted that among the components of love of money, it is Evil $\left(\mathrm{r}=.750^{* *}, \mathrm{p}<.01\right)$ and the desire to Succeed $\left(\mathrm{r}=.389^{* *}\right.$, sig. $\left.<.01\right)$ that are positively related to unethical marketing behavior. These results indicated that if the salespersons are willing to perform unprofessional assignments for monetary gain or if they have a burning desire for success regardless how they succeed, this is bound to result into unethical marketing behavior. This supports Hypothesis One which stated that the love of money is positively correlated to Unethical Marketing Behaviors.

\section{Insert Table 3}

We post a positive relationship between pressure to perform and unethical marketing Behavior $(r=0.335, p-$ value $<0.01)$. It was noted that among the components of pressure to perform. It is Target $\left(r=.326^{* *}, p<.05\right)$ and Deadline $\left(\mathrm{r}=.233^{* *}\right.$, sig. <.01) that are positively related to unethical Marketing Behavior. This means that as pressure to perform increases through the achievement of Targets and Deadlines, unethical marketing behavior increases and moves in the same direction as a result of the effect. Unrealistic Targets combined with fixed Deadlines promote and strengthen unethical Marketing Behavior. This supports hypothesis two, which stated that Pressure to perform is positively correlated to unethical behaviors of sales personnel. A significant negative relationship between Management Control and Unethical marketing Behavior $\left(\mathrm{r}=-0.293^{* *}, \mathrm{p}-\right.$ value $\left.<0.01\right)$ is posted. The results show that love of money through its components can be moderated by management control since there is a positive relationship. It is Equity $\left(\mathrm{r}=.191^{*}, \mathrm{p}<.05\right)$. This means that as management control improves, unethical marketing behavior is eliminated or reduced. This finding supports hypothesis three which stated that Management control moderates between love of money, Pressure to perform, and unethical marketing behaviors of sales personnel.

We used multiple regression analysis to examine the level to which the Love of Money, Pressure To Perform and Management Control can predict the level of Unethical Marketing Behavior. Table 4 below presents the regression model.

\section{Insert Table 4}

The predictor variables in the regression, can explain up to $46.8 \%$ of the variance in Unethical Marketing Behavior (Adjusted R Square $=.468$ ). Among the predictors, results show that the love of money (Beta $=.628$, sig. $<.01)$ is more influential at explaining the Unethical Marketing behavior than Pressure to Perform (Beta = 0.05 , Sig. $<.01$.) and Management Control (Beta $=-0.131$ Sig. $<.01$.). The regression model was valid (sig. $<.01$ ). This means $53.2 \%$ of the variation in unethical Marketing Behavior remains unexplained.

ANOVA was presented to rank the salespersons residing in rural and urban areas on the study variables.

\section{Insert Table 5}

It was noted that salespersons residing in Urban Areas (Mean $=2.472)$ ranked higher than their counterparts staying in Rural Areas (Mean = 2.093) and there were significant differences between these two categories of sales persons on this key variable (sig. <.001). It therefore means that urban dwellers loved money more and were more inclined to engage in unethical marking behavior that their counterparts in rural areas. 


\section{Discussion, conclusion and recommendations}

The Spearman's correlation coefficient shows that there is a significant positive relationship between love of money and unethical marketing behavior consistent with Tang and Chiu (2003) findings. Tang and Chiu (2003) found that the love of money other than money per-se is the cause of unethical behaviors. They analyzed this by money profiles measured using Money Ethic Scale (MES) or Love of Money Scale (LOM) since money profiles have a direct impact on work-related attitudes (Li-Ping Tang, Shin-Hsiung Tang and Luna-Arocas, 2005) therefore affect the marketing behaviors of sales people. Similarly, the factor evil is the affective component of the money attitude and according to this factor; people believe that the love of money is the cause of all undesirable behaviors (Tang, et al, 2002 in Tang, et al, 2003). This leads to the perception that money is dirty and hence individuals with such a belief have developed hatred for it. Therefore, love of money is seen as an important attribute to unethical Marketing Behavior. This supports the scripture in the Bible that warn: "For the love of money is a root of all kinds of evil..." (1Timothy 6:10, P.2050 New King James Version Study Bible). Furnham \& Argyle, 1998 in Tang et al, 2003) also contends that factor success emphasizes money as an indicator of status in society leading to some people being obsessed with money to prove their successes. Omagor et al (2009) asserted that, love of money is mainly associated with need for survival and success other than evil perspective. These unethical practices are still daily phenomena in press, and there are continuous occurrences of wrongdoing.

This study posts a significant positive relationship between pressure to perform and unethical marketing behavior. Putting sales people under pressure is mostly likely to lead to unethical marketing behaviors. The degree of fear and pressure associated with meeting numerical goals and targets also play a major role in fraud availability. Robertson and Anderson (1993) argue that as salespeople become more established financially and professionally, they experience some alleviation of the pressure to take shortcuts. Consequently, salespeople who have achieved this standing have the knowledge and skills at hand to be able to resolve ethical dilemmas without the need to violate ethical norms. The same logic can be applied to sales teams in which salespeople have high levels of tactical selling competence. Individuals in these teams can, if they so choose, use the skills they have developed to resolve the ethically-questionable choices they will face without the need to cut corners or break societal norms. This is further supported by Ross and Robertson (2003) who noted that performance pressure is a factor which has been shown to affect ethical behavior. It is believed that compensation methods relying on commission, quotas and bonuses are likely to exacerbate ethical problems in sales teams, since these kinds of remuneration systems transfer risk to salespeople, and put financial pressure on them to get sales results (Roman \& Munuera, 2005; Tang, et al, 2008).

The findings of the study indicate that the relationship between management control and unethical marketing behavior is significant with negative correlation. So acting in good faith, directors and management will ensure proper corporate governance and shareholder wealth maximisation. Management controls and ethical standards may therefore influence ethical marketing behaviors as measured by looking at the availability and strength of ethical standards as well as management commitment to ethical values. This was emphasized by Cadogan, et al (2009) who asserted that in the event of unethical dilemmas, sales people will most likely engage in unethical marketing behaviors when the ethical standards and controls are not properly managed. This is consistent with the belief; achieving success in business and earning the respect of others, requires diligence on the part of a great number of people. Yet the unethical actions of one or two individuals can undermine that hard-earned reputation. Omagor et al (2009) suggested that the area of residence might predict the tendency to engage in unethical behaviour. Nevertheless people's propensity to engage in unethical behaviour may not base on residence but merely on greed and responsibility (dependants). Our findings however indicated that married people tend to engage in unethical behaviour more especially those who reside in urban areas.

This study confirms that the main objective of love of money not only includes involvement in unethical marketing behavior but also highlights the importance of evaluating and improving management control. Effective management control function clearly correlates with an organization's success in meeting management objectives and whether the control system is functioning as intended. Pressure to perform plays a unique and critical role in designing appropriate measures by monitoring organizational targets and deadlines. A sales person should also be able to evaluate the indicators of success and decide whether to engage in unethical marketing behavior. This study indicates that salespersons that reside in urban areas and are married tend to engage more in unethical marketing behavior. This is attributed to the fact that greed and desire to have a luxurious lifestyle influences their attitudes to love of money. A company's system of controls has a key role in shaping the tone at the top management that is significant to the fulfillment of its business objectives. It is important to note therefore, that a sound control provides reasonable, but not absolute, assurance that a 
salesperson will not be enticed in to participating in unethical behaviors which may seem to be unacceptable or illegal in the process of achieving business objectives by circumstances which may reasonably be foreseen.

Management should educate employees to realize that love of money can lead to unethical marketing behavior. This would help employees to be good stewards of the company money which would save them from early termination of their employment. For example in cosmetics and banking industries, employees who are involved in money scandals are blacklisted and cannot be employed in the same industry anymore. Management should create an environment of recognizing the experience of senior people and pay them very well which will minimize the love of money and eventually unethical marketing behavior hence creating a cadre of ethically committed employees.

Companies should adopt a system of paying sales persons purely on commission which can eventually motivate them since there is no limit of how much money they can earn. Future research should establish other factors other than the love of money, pressure to perform; to explain unethical marketing behavior in the cosmetic industry in Uganda

\section{References}

Applebaum, S., Iaconi, G.D., and Matousek, A. (2007). Positive and negative deviant workplace behaviours: Causes, impacts and solutions. Corporate Governance, Vol. 7, pp. 586-598. http://dx.doi.org/10.1108/14720700710827176

Barigaba, J. (2009). Untested meters spark of fear over high bills. The East African, No.778, September 28-October 4, 2009, p1 \& 6 .

Boedecker, K.A., Morgan, F.W., \& Stoltman, J.J. (1991). Legal dimensions of salesperson's statements: A review and managerial suggestions. Journal of Marketing, 55, 70-80. http://dx.doi.org/10.2307/1252204

Cadogan, W. J., Lee, N., Tarkiainen, A., and Sundqvist, S. (2009). Sales manager and sales team determinants of sales person ethical behavior. European Journal of Marketing, Vol.43, No.7/8, 2009, pp.907-937. http://dx.doi.org/10.1108/03090560910961452

(The) Committee of Sponsoring Organizations of the Treadway Commission (COSO). (2009). Guidance on Monitoring Internal Control Systems. [Online] Available: http://www.Coso.org/documents/COSO_Guidance_On_Monitoring_Intro_online.pdf

Furnham, A., \& Argyle, M. (1998). The Psychology of Money. Routledge, London.

Gundlach, G.T., and Murphy, P.E. (1993). Ethical and legal foundations of relational marketing exchanges. Journal of Marketing, Vol. 57, No. 4, pp. 35-46. http://dx.doi.org/10.2307/1252217

Hair, J.F. Jr., Anderson, R.E., Tatham, R.L., \& Black, W.C. (1998). Multivariate Data Analysis. (5th Edition). Upper Saddle River, NJ: Prentice Hall.

Human Resource Managers Reports. (2004-2009). Presentation at the Annual Board meeting.

Nicklaus. D.J., and King, E. W. (2009). A Study of the Effect of Age and Gender upon Students. Journal of Business Ethics, 11, 179-186.

Kline, R. B. (2005). Principles and Practice of Structural Equation Modeling. (2nd ed.). New York: Guilford ISBN 978-1-57230-690-5.

Krejcie, R.V., \& Morgan, D.W. (1970). Determining sample size for research activities. Educational and Psychological measurement, Vol. 30, pp. 607-610.

Lane, J.C. (1995). Ethics of business students: some marketing perspectives. Journal of Business Ethics, 14, 571-580. http://dx.doi.org/10.1007/BF00871985

Li-Ping Tang, T., Shin-Hsiung Tang, D., and Luna-Arocas , R. (2005). Money profiles: the love of money, attitudes, and needs. Personnel Review, Vol. 34, No. 5, pp.603-618. http://dx.doi.org/10.1108/00483480510612549

Marketing Manager's end of year report. (Dec.2009). Business Times, Vol. 2.

Mohamed, M. (2007). A study of Machievellian Orientation among Marketing students in Egypt. College Student Journal. Egypt.

Omagor, C., Mubiru, M.P., and Nkuutu, G. (2009). The love of money, Machiavellianism and Unethical behaviour: A study of MUBS students. Conference paper, Annual International Management Conference, Makerere University Business School, November, 2009. 
Rayburn, M.J., and Rayburn, G.L. (1996). Relationship Between Machiavellianism and Type A Personality and Ethical-Orientation. Journal of Business Ethics, Vol. 15, No. 11, pp. 1209-1219. http://dx.doi.org/10.1007/BF00412819

Robertson, D.C., \& Anderson, E. (1993). Control system and task environment effects on ethical judgment: an exploratory study of industrial salespeople. Organization Science, Vol. 4 pp.617-45. http://dx.doi.org/10.1287/orsc.4.4.617

Roman, S., and Munuera, J. L. (2005). Determinants and consequences of ethical behavior: an empirical study of salespeople. European Journal of Marketing, Vol. 39, No. 5/6, pp. 473-495. http://dx.doi.org/10.1108/03090560510590674

Ross, W.T., \& Robertson, D.C. (2003). A typology of situational factors: impact on salesperson decision-making about ethical issues. Journal of Business Ethics, Vol. 46, pp.213-34. http://dx.doi.org/10.1023/A:1025563624696

Royal Netherlands Embassy (2003). Uganda: The Fight against Corruption: A case study on the prevalence of corruption in Uganda, specifically in Local Government, Education, Justice, Law \& Order, and Procurement. [Online] Available: http://www.u4.no/document/showdoc.cfm?id=94.

Singhapakdi, A., Vitell, S.J., \& Franke, G.R. (1999). Antecedents, consequences, and mediating effects of perceived moral intensity and personal moral philosophies. Journal of the Academy of Marketing Science, Vol. 27, pp.19-36. http://dx.doi.org/10.1177/0092070399271002

Slowan, A. (2002). The jury's in: greed isn't good. News week, 24. June, pp.37.

Study IDs Leading Factors for Unethical Behaviour. [Online] Available: http://hr.blr.com/HR-news/HR-Administration/Workplace-Ethics/Study-IDs-Leading-Factors-for-Unethical-Beh aviour/ (December 18 ${ }^{\text {th }}, 2009$ ).

Tang, T. L., and Chiu, R. K. (2003). Income, Money Ethic, Pay Satisfaction, Commitment, and Unethical Behaviour: Is the Love of Money the Root of Evil for Hong Kong Employees? Journal of Business Ethics, 46: 13-30. http://dx.doi.org/10.1023/A:1024731611490

Tang, T. L., Tang, D. S., and Luna-Arocas, R. (2005). Money profiles: the love of money, attitudes, and needs. Personnel Review. Vol. 34, No. 5, pp 603-618. http://dx.doi.org/10.1108/00483480510612549

Tang, T.L., and Chen, Y. (2008). Intelligence vs wisdom: the love of money, Machiavellianism, and unethical behavior across college major and gender. Journal of Business Ethics, Vol. 82, pp. 1-26. http://dx.doi.org/10.1007/s10551-007-9559-1

Tang, T.L., Chen, Y., and Sutarso, T. (2008). Bad apples in bad (business) barrels: The love of money, Machiavellianism, risk tolerance, and unethical behavior. Management Decision, Vol. 46, No. 2, pp. 243-263. http://dx.doi.org/10.1108/00251740810854140

Yu, T.Y., and Dean, A. (2001). The contribution of emotional satisfaction to consumer loyalty. International Journal of Service Industry Management, Vol. 12, No. 3, pp. 234-250. http://dx.doi.org/10.1108/09564230110393239

Table 1. Distribution of the sample

\begin{tabular}{|c|c|c|c|c|c|c|c|c|c|c|c|}
\hline & & \multicolumn{9}{|c|}{ Population } & \multicolumn{5}{c|}{ Sample size } \\
\hline No. & Company & SR & SM & SS & RM & Total & SR & SM & SS & RM & Total \\
\hline $\mathbf{1}$ & Movit & 80 & 5 & 10 & 5 & 100 & 44 & 3 & 6 & 3 & 56 \\
\hline $\mathbf{2}$ & Samona & 50 & 4 & 10 & 6 & 70 & 28 & 2 & 6 & 3 & 39 \\
\hline $\mathbf{3}$ & Nevia & 28 & 3 & 6 & 3 & 40 & 16 & 2 & 4 & 1 & 23 \\
\hline $\mathbf{4}$ & Neem & 47 & 5 & 3 & 5 & 60 & 26 & 3 & 2 & 3 & 34 \\
\hline $\mathbf{5}$ & Desire & 25 & 3 & 1 & 1 & 30 & 14 & 1 & 1 & 1 & 17 \\
\hline & Total & 230 & 20 & 30 & 20 & 300 & 128 & 11 & 19 & 11 & 169 \\
\hline
\end{tabular}

Note: The above table 1 shows how the sample for the present study was derived. SR= Sales Representatives, $\mathrm{SM}=$ Sales Managers, $\mathrm{SS}=$ Sales Supervisors, $\mathrm{RM}=$ Regional Managers 
Table 2. Cronbach's alpha $(\alpha)$ coefficient for the study variables

\begin{tabular}{|c|l|c|c|}
\hline Variable & Anchor & Cronbach Alpha Value & CVI \\
\hline Management Control & 4 point & .7316 & 0.880 \\
\hline Love of Money & 4 point & .5095 & 0.625 \\
\hline Pressure To Perform & 4 point & .5571 & 0.778 \\
\hline Unethical Marketing Behavior & 4 point & .9495 & .9030 \\
\hline
\end{tabular}

Note: Table 2 above indicates the Content Validity Indices (CVI) and Crobach Alpha Values that test for the validity and reliability of the questions and the instrument respectively.

Table 3. Spearman's correlation matrix for the study variables

\begin{tabular}{|c|c|c|c|c|c|c|c|c|c|c|c|}
\hline & 1 & 2 & 3 & 4 & 5 & 6 & 7 & 8 & 9 & 10 & 11 \\
\hline Budget-1 & 1.000 & & & & & & & & & & \\
\hline Evil-2 & $-.179 *$ & 1.000 & & & & & & & & & \\
\hline Equity-3 & $.283^{* *}$ & $-.429 * *$ & 1.000 & & & & & & & & \\
\hline Desire for Success-4 & $-.328 * *$ & $.309^{* *}$ & $-.283 * *$ & 1.000 & & & & & & & \\
\hline Motivator-5 & $.271^{* *}$ & $-.525 * *$ & $.458^{* *}$ & $-.353 * *$ & 1.000 & & & & & & \\
\hline Love of Money-6 & $-.563 * *$ & $.736^{* *}$ & $-.724 * *$ & $.645^{* *}$ & $-.767 * *$ & 1.000 & & & & & \\
\hline Targets-7 & $-.227 *$ & $.391 * *$ & $-.300 * *$ & .172 & $-.343 * *$ & $.419 * *$ & 1.000 & & & & \\
\hline Deadlines-8 & $-.195 *$ & .174 & -.032 & .125 & -.095 & .174 & $.240 * *$ & 1.000 & & & \\
\hline Pressure To Perform-9 & $-.285 * *$ & $.339^{* *}$ & $-.203 *$ & $.196^{*}$ & $-.286 * *$ & $.379 * *$ & $.792 * *$ & $.795 * *$ & 1.000 & & \\
\hline $\begin{array}{l}\text { Management } \\
\text { Control-10 }\end{array}$ & .020 & $-.250 * *$ & $.191^{*}$ & $-.238 * *$ & .107 & $-.244 * *$ & -.165 & $-.271 * *$ & $-.273 * *$ & 1.000 & \\
\hline $\begin{array}{l}\text { Unethical Marketing } \\
\text { Behaviour-11 }\end{array}$ & $-.222 *$ & $.750^{* *}$ & $-.414 * *$ & $.389^{* *}$ & $-.486 * *$ & $.675^{* *}$ & $.326^{* *}$ & $.233 * *$ & $.335 * *$ & $-.293 * *$ & 1.000 \\
\hline \multicolumn{12}{|c|}{ * Correlation is significant at the 0.05 level (2-tailed). } \\
\hline$* *$ Correlation is signi & int at t & $.01 \mathrm{le}$ & 2-tail & & & & & & & & \\
\hline
\end{tabular}

Table 4. Regression model

\begin{tabular}{|l|l|l|l|l|l|}
\hline & \multicolumn{2}{|l|}{$\begin{array}{l}\text { Unstandardized } \\
\text { Coefficients }\end{array}$} & $\begin{array}{l}\text { Standardized } \\
\text { Coefficients }\end{array}$ & $\mathbf{t}$ & Sig. \\
\hline Model & B & Std. Error & Beta & & \\
\hline Constant & .159 & .513 & & .310 & .757 \\
\hline Love of Money & .994 & .113 & .628 & 8.770 & .000 \\
\hline Pressure To Perform & .081 & .113 & .052 & .718 & .474 \\
\hline Management Control & -.162 & .085 & -.131 & -1.907 & .059 \\
\hline Dependent Variable: Unethical Marketing Behaviour \\
\hline R Square & 0.481 & F Change & 37.357 & \\
\hline Adjusted R Square & 0.468 & Sig. & 0.000 & \\
\hline
\end{tabular}

Note: Table 4 above aims to disclose the coefficient of determination as adjusted and shows the predictive power of the predictors with love of money emerging as the biggest contributor to unethical marketing behavior.

Table 5. Analysis of variance

\begin{tabular}{|c|c|c|c|c|c|c|}
\hline & & Mean & Std. Deviation & Std. Error & $\bar{F}$ & Sig. \\
\hline \multirow{2}{*}{ Love of Money } & Urban & 2.472 & 0.630 & 0.060 & \multirow{2}{*}{6.197} & \multirow{2}{*}{.014} \\
\hline & Rural & 2.093 & 0.612 & 0.137 & & \\
\hline \multirow{2}{*}{ Management Control } & Urban & 2.972 & 0.829 & 0.080 & \multirow{2}{*}{.367} & \multirow{2}{*}{.546} \\
\hline & Rural & 2.850 & 0.813 & 0.182 & & \\
\hline $\begin{array}{l}\text { Unethical Marketing } \\
\text { Behaviour }\end{array}$ & $\begin{array}{l}\text { Urban } \\
\text { Rural }\end{array}$ & $\begin{array}{l}2.473 \\
1.778\end{array}$ & $\frac{1.002}{0.943}$ & $\begin{array}{l}0.096 \\
0222\end{array}$ & 7.559 & .007 \\
\hline
\end{tabular}

Note: Table 5 above is the ANOVA table comparing the ratio of systematic variance to unsystematic variance (the F-ratio) and is indicating that the group means are significantly different. 